\title{
APLIKASI PERMAINAN SUSUN KATA UNTUK PEMBELAJARAN BAHASA INGGRIS DENGAN ALGORITMA KNUTH-MORRIS-PRATT DAN FISHER-YATES SHUFFLE
}

\author{
${ }^{1}$ Suryo Hadi Sampurno, ${ }^{2}$ A'la Syauqi, M.Kom. \\ ${ }^{12}$ Teknik Informatika \\ Fakultas Sains dan Teknologi \\ Universitas Islam Negeri Maulana Malik Ibrahim Malang \\ email: suryaduasatu@gmail.com
}

\begin{abstract}
Abstrak -Proses pembelajaran bahasa Inggris tentu perlu mempelajari tentang tata bahasa Inggris (grammar). Dengan definisi, rumus, dan contohnya yang cukup rumit, aplikasi komputer interaktif (game) yang memuat konten edukasi bahasa Inggris ini hadir sebagai hiburan yang mendidik. Penggunaan game susun kata sebagai sarana edukasi dikarenakan sifatnya yang interaktif sekaligus menghibur. Pemain diminta aktif untuk merangkai kata menjadi kalimat yang sesuai dengan tata bahasa tertentu. Permainan dibangun dengan mengimplementasikan metode Knuth-Morris-Pratt pada proses koreksi susunan kata dan metode Fisher-Yates shuffle pada proses membangkitkan permutasi susunan soal. Hasil uji coba metode Knuth-Morris-Pratt didapatkan hasil akurasi sebesar $100 \%$ dengan konsumsi waktu rata-rata adalah $4,133403 \times 10^{-4}$ detik menunjukkan proses koreksi susunan kata pada permainan berjalan efektif dari segi akurasi dan konsumsi waktu. Hasil uji coba metode Fisher-Yates shuffle didapatkan frekuensi permutasi dengan nilai ratarata range sebesar $1,61 \%$ menunjukkan permutasi acak dari suatu himpunan terhingga terdistribusi secara hampir merata sehingga susunan soal yang ditampilkan permainan seimbang dan lebih bervariasi.
\end{abstract}

Kata Kunci: Bahasa Inggris, aplikasi komputer interaktif, Knuth-Morris-Pratt, FisherYates shuffle

\section{PENDAHULUAN}

Bahasa Inggris saat ini merupakan bahasa yang paling umum digunakan di seluruh dunia. Bahasa ini telah digunakan secara luas pada bidang pengetahuan, pendidikan, perdagangan, politik, dan teknologi. Bahasa Inggris saat ini menjadi bahasa utama dan secara tidak resmi dianggap sebagai lingua franca di berbagai belahan dunia bagi yang menggunakannya sebagai bahasa ibu/utama, bahasa kedua, dan bahasa asing (Wardhaugh, 2010). Berdasarkan fakta tersebut mempelajari bahasa Inggris menjadi penting dan sebagai suatu kebutuhan. Melalui penguasaan bahasa Inggris, masyarakat diharapkan mampu berkomunikasi di kancah internasional serta dapat menguasai ilmu pengetahuan dan teknologi yang pada umumnya ditulis dalam bahasa Inggris.

Pada proses belajar bahasa Inggris tentu pelajar perlu mempelajari tentang tata bahasa Inggris (grammar). Pemahaman tentang tata bahasa dalam belajar bahasa Inggris sangat penting. Karena penggunaan bahasa yang benar harus mengikuti aturan tata bahasanya sehingga pelajar diharapkan memiliki keterampilan dan menjadi terlatih dalam membaca, menulis, berbicara, memahami, dan membuat serta menyusun kata dan kalimat secara benar. Namun tata bahasa Inggris semisal grammatical tense dengan segala definisi, rumus, dan contohnya seringkali dianggap sebagai kesulitan dalam belajar bahasa Inggris. Karena pada praktiknya pelajar seringkali menghafal banyak rumus disertai pembahasannya yang cukup rumit.

Untuk membantu pelajar mempelajari tata bahasa Inggris diluar pendidikan formal yang telah dilakukan maka pada penelitian ini dibuat sebuah Aplikasi komputer interaktif yang berbentuk game. Penggunaan game sebagai sarana edukasi dikarenakan sifatnya yang interaktif sekaligus menghibur. Dalam permainan, pembelajaran dilakukan lewat praktek 
atau learning by doing. Sehingga konten edukasi tersampaikan kepada pemain dengan cara menyenangkan, serta tidak membosankan.

Aplikasi komputer interaktif ini dibuat dengan tujuan untuk memberikan suatu nilai edukasi kepada pemain. Aplikasi ini akan meminta pemain untuk aktif merangkai kata-kata menjadi kalimat yang sesuai dengan tata bahasa (grammar) tertentu. Sehingga secara tidak langsung akan melatih kemampuan membaca (reading skill) dan juga kemampuan menulis (writing skill) pemain.Diharapkan dengan adanya media alternatif pembelajaranberupa aplikasi komputer interaktif ini dapat berkontribusi terhadap peningkatan atau menumbuhkan minat pelajar dalam mempelajari tata bahasa Inggris.

Aplikasi berupa game tentang tata bahasa Inggris ini dibangun dengan meng-implementasikan metode KnuthMorris-Pratt pada proses koreksi susunan kata dan metode Fisher-Yates shuffle pada proses membangkitkan susunan soal.Untuk menilai keberhasilan implementasi maka akan diukur akurasi dan konsumsi waktu terhadap implementasi metode Knuth-MorrisPratt sebagai proses koreksi susunan kata dan diukur permutasi yang dihasilkan terhadap implementasi metode Fisher-Yates shuffle pada proses membangkitkan susunan soalpada aplikasi komputer interaktif.

\section{TINJAUAN PUSTAKA}

\section{A. Knuth-Morris-Pratt}

Algoritma Knuth-MorrisPrattdipilih untuk diterapkan pada pembuatan aplikasi komputer interaktif ini dibandingkan dengan algoritma string matching lain karenamemberikan hasil yang efektif dari segi waktu komputasi(Soleh, 2010) dan (Lestari \& Djaya, 2011) serta lebih cepat dibandingkan dengan algoritma Brute Force(Hadiati, 2007),(Pandiselvam.P et al., 2014) dan (Mulyana, 2014).

Knuth-Morris-Pratt(KMP)

merupakan metode exact string matching yang menerapkan arah pencarian dari kiri ke kanan. metode Knuth-Morris-Pratt melakukan pencarian kata $P$ terhadap teks $T$ dengan menggunakan pengamatan bahwa ketika terjadi ketidakcocokan, kata itu sendiri memberikan informasi untuk menentukan dimana perbandingan berikutnya bisa dimulai, sehingga melewati pencocokan ulang karakter sebelumnya. Dengan demikian metode $K M P$ melakukan pergeseran lebih jauh sesuai dengan informasi ketidakcocokan yang disimpan sehingga waktu pencarian dapat dikurangi secara signifikan. Perhatikan posisi karakter terjadinya ketidakcocokan untuk pertama pada teks berikut:

Contoh 1:

$$
\begin{aligned}
& \mathrm{T}=\text { ?????????? ?? ?? ?? ? } \\
& \mathrm{P}=\text { aaabaaaxyz } \\
& \text { ^ }
\end{aligned}
$$

Dapat dipastikan bahwa karakter sebelumnya (prefix) sama dengan pattern $\mathrm{P}$

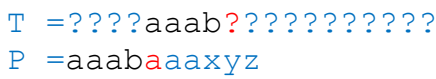

Kemudian gunakan informasi prefix ini untuk mencocokkan string. Maka dapat dipastikan jika pattern $\mathrm{P}$ tidak akan ditemukan jika pencocokan dimulai pada posisi berikut:

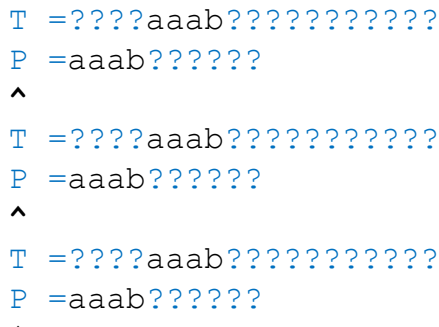

Kemungkinan pertama ditemukan kecocokan adalah jika pencocokan dimulai pada posisi berikut:

$$
\begin{aligned}
& \mathrm{T}=\text { ????aabb??????????? } \\
& \mathrm{P}=\quad--->a \mathrm{ab} \text { ?????? } \\
& \wedge(4 \text { char slide) }
\end{aligned}
$$

Berdasarkan contoh 1 dapat diambil kesimpulan bahwa proses pencocokan dapat digeser sebanyak 4 karakter tanpa melakukan pencocokan yang tidak diperlukan dan melewatkan satupun pola kecocokan pattern $\mathrm{P}$. 
Metode Knuth-Morris-Pratt memberikan hasil yang efektif dari segi waktu komputasi karena proses pencocokan tidak selalu dilakukan dengan menggeser ke kanan 1 karakter. Untuk melakukan pencarian yang efektif metode ini memiliki dua poin utama yaitu prefix function dan KMP matcher:

- Prefix fuction menyimpan informasi tentang kecocokan pattern dan informasi ini digunakan untuk menghindari pergeseran yang tidak diperlukan pattern. Berikut ini adalah pseudocode prefix function (Cormen et al., 2009):

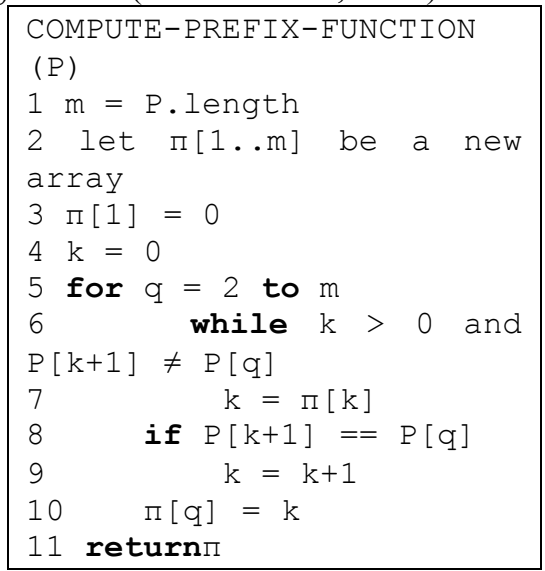

- KMP matcher menggunakan prefix function, pattern dan teks sebagai input untuk menemukan pattern pada teks dan mengembalikan jumlah pergeseran setelah ditemukan pola pertama. Berikut ini adalah Pseudocode KMP matcher (Cormen et al., 2009):

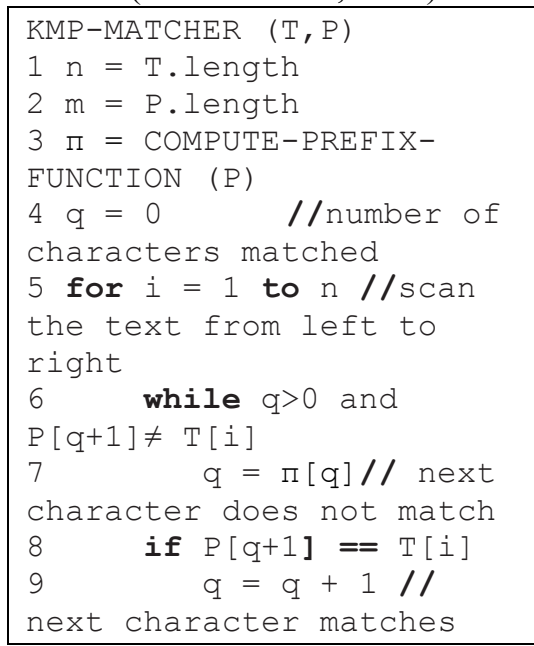

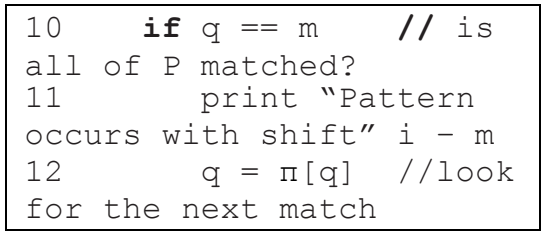

B. Fisher-Yates shuffle

Fisher-Yates shuffle atau juga disebut sebagai Knuth shuffle adalah sebuah metode untuk menghasilkan sebuah permutasi acak dari suatu himpunan terhingga. Metode FisherYates shuffle memungkinkan setiap permutasi yang dihasilkan memiliki kemungkinan yang sama (unbiased). Metode ini memiliki time complexcity O(n) (Black, 2005). Berikut ini adalah pseudocode:

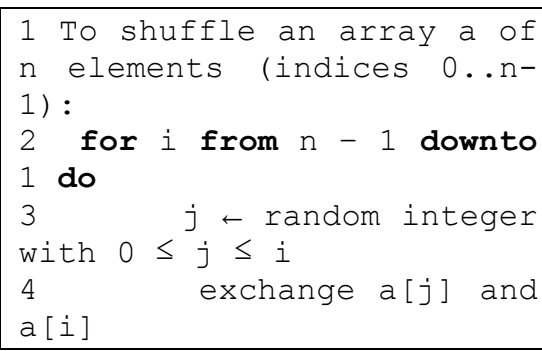

Berikut ini adalah contoh pengerjaan untuk permutasi angka 1-8:

\begin{tabular}{|c|c|c|c|}
\hline Range & Roll & Scratch & Result \\
\hline & & 12345678 & \\
\hline
\end{tabular}

Pertama kita pilih angka acak 1-8, kita pilih 6 kemudian kita menukar angka urutan keenam yaitu angka 6 dengan angka urutan kedelapan yaitu angka 8

\begin{tabular}{|c|c|c|c|}
\hline Range & Roll & Scratch & Result \\
\hline $1-8$ & 6 & $\begin{array}{c}123458 \\
7\end{array}$ & $\mathbf{6}$ \\
& & \multicolumn{2}{|c|}{} \\
\hline
\end{tabular}

Angka acak selanjutnya dari 1-7, kita pilih 2. Kita tukar angka urutan kedua dan ketujuh

\begin{tabular}{|c|c|c|c|}
\hline Range & Roll & Scratch & Result \\
\hline $1-7$ & 2 & $\begin{array}{c}17345 \\
8\end{array}$ & $\mathbf{2 6}$ \\
& & \multicolumn{2}{|c|}{} \\
\hline
\end{tabular}

Angka acak berikutnya dari 1-6, 1-5 dan seterusnya. Sehingga dengan mengulangi langkah-langkah seperti diatas akan didapatkan hasil sebagai berikut:

Tabel 1. Pengerjaan metode FisherYates shuffle

\begin{tabular}{|c|c|r|c|}
\hline Range & Roll & \multicolumn{1}{|c|}{ Scratch } & Result \\
\hline $1-6$ & 6 & 17345 & $\mathbf{8 2} 6$ \\
\hline $1-5$ & 1 & $\mathbf{5 7 3 4}$ & $\mathbf{1 8 2 6}$ \\
\hline
\end{tabular}




\begin{tabular}{|l|l|r|l|}
\hline $1-4$ & 3 & $57 \mathbf{4}$ & $\mathbf{3} 1826$ \\
\hline $1-3$ & 3 & 57 & $\mathbf{4 3} 1826$ \\
\hline $1-2$ & 1 & $\mathbf{7}$ & $\mathbf{5 4 3 1 8 2 6}$ \\
\hline
\end{tabular}

Permutasi yang dihasilkan adalah 754 31826 .

\section{METODE PENELITIAN}

\section{A. Prosedur Penelitian}

Tahap awal dilakukan Analisis meliputi analisis literatur, analisis permainan, analisis input, analisis proses, dan analisis output. Kemudian tahap Desain meliputi desain use case diagram, desain activity diagram, desain class diagram dan desain interface. Dilanjutkan tahap Implementasi meliputi implementasi interface, implementasi metode Knuth-MorrisPratt dan implementasimetode FisherYates shuffle. Selanjutnya tahap Uji coba dan Evaluasi meliputi uji coba metode Fisher-Yates shuffle dan uji coba metode Knuth-Morris-Pratt, kemudian evaluasi berdasarkan hasil uji coba. Tahap terakhir adalah Dokumentasiyang merupakan kegiatan penulisan laporan sebagai dokumentasi dari keseluruhan tahapan yang telah dilaksanakan.

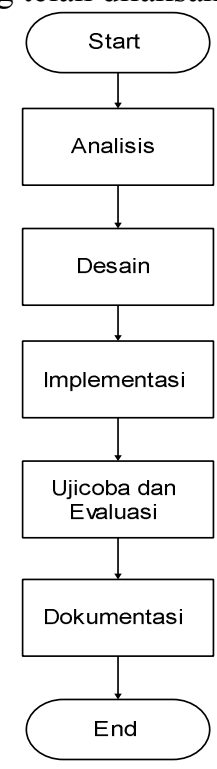

Gambar 1.Flowchart prosedur penelitian

\section{B. Analisis Permainan}

Konsep dari permainan ini adalah pemain diberikan sebuah field permainan berupa kotak-kotak sebanyak
54 (6 x 9) kotak dan memuat subject, verb, noun, pronoun dan lain sebagainya. Pemain akan diminta untuk menyusun kata-kata/membuat kalimat bahasa Inggris berdasarkan soal yang muncul. Pemain melakukan klik pada kotak yang ada, apabila kalimat yang dibuat benar maka pemain akan mendapatkan skor.Berdasarkan konsep permainan tersebut kemudian diimplementasikan metode KnuthMorris-Pratt pada proses koreksi susunan kata dengan membandingkan kalimat jawaban pemain terhadap kunci jawaban yang tersimpan dalam database.

\section{Analisis Input}

Database soal dan jawaban yang digunakan merupakan kalimatkalimat yang mempunyai struktur tata bahasa Inggris. Tata bahasa Inggris yang digunakan pada permainan ini antara lain: Simple Present, Simple Present Continuous, Simple Past, dan Simple Future (will).Database soal dan jawaban berupa dokumen teks (.txt) mempunyai format: kalimat-bahasa-inggris;artikalimat.Diantara kalimat bahasa Inggris dan arti kalimat dipisahkan oleh tanda semicolon (;). Antar kata pada kalimat bahasa Inggris dan arti kalimat dipisahkan oleh dash (-).

\section{Analisis proses permutasi}

Permutasi adalah proses mengubah letak urutan dari suatu grup/himpunan dengan memperhatikan urutan. Apabila urutan diperhatikan dan setiap objek yang tersedia hanya bisa dipilih atau dipakai sekali maka jumlah permutasi yang ada dapat dihitung dengan rumus:

$$
P(n, r)=\frac{n !}{(n-r) !}
$$

di mana $n$ adalah jumlah objek yang dapat dipilih, $r$ adalah jumlah yang harus dipilih dan! adalah simbol faktorial. Proses permutasi pada aplikasi digunakan untuk menentukan soal-soal yang akan ditampilkan pada field permainan sehingga soal yang ditampilkan lebih bervariasi dan seimbang. Metode yang 
diimplementasikan pada proses ini adalah Fisher-Yates shuffle.

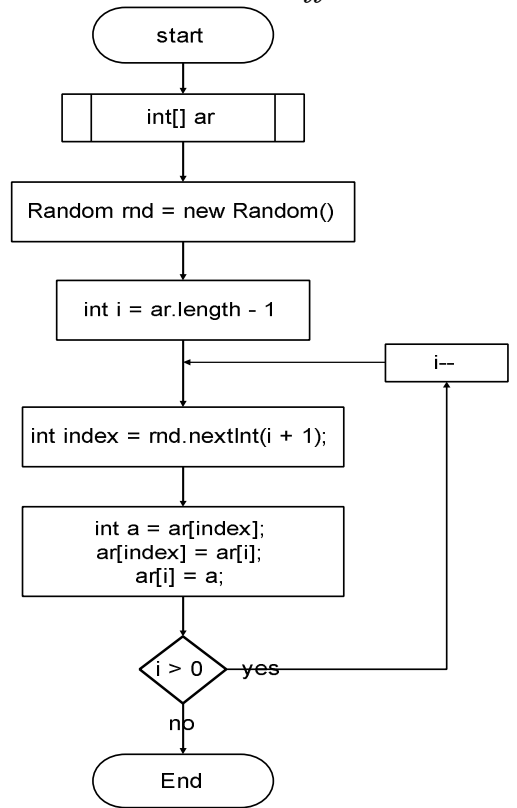

Gambar 2.Flowchart proses permutasi metode Fisher-Yates Shuffle

\section{E. Analisis proses koreksi}

Proses koreksi susunan kalimat menggunakan metode Knuth-MorrisPrattmelibatkan dua parameter yaitu pattern $\mathrm{P}$ (kalimat) yang akan dicari dan text $\mathrm{T}$ yang merupakan databaseserta melakukan dua proses yaitu fase preprosessing dan fase pencarian.

Pada fase preprosessing metode KMP membuat temporarry arrayPrefix fuction dari pattern $\mathrm{P}$, п. п merupakan sebuah array berukuran (P.length) dimana untuk setiap $\Pi[i]$ terhadap $P$, п[i] didefinisikan sebagai 'panjang terpanjang dari proper suffix $[i]$ ' yang cocok dengan 'properprefix dari P [i]'.

Pada fase pencarian kita mengkomparasikan karakter pertama dari teks $T$ T [i]dengan karakter pertama dari pattern P P[i].Jika ditemukan kesamaan maka nilai idanq akan dinaikkan. Jika ditemukan ketidaksamaan lalu kita lihat pada nuntuk menggeser posisi dari $P$ sebanyak nilai yang didasarkan pada perhitungan Prefix fuction dari pattern $\mathrm{P}, \Pi$.

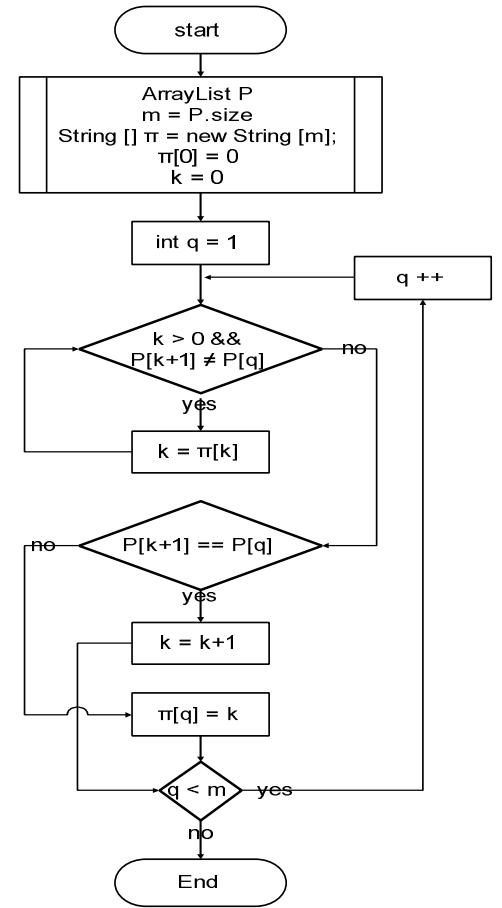

Gambar 3.FlowchartFase preprosessing: menghitung Prefix fuction dari pattern $P, \pi$

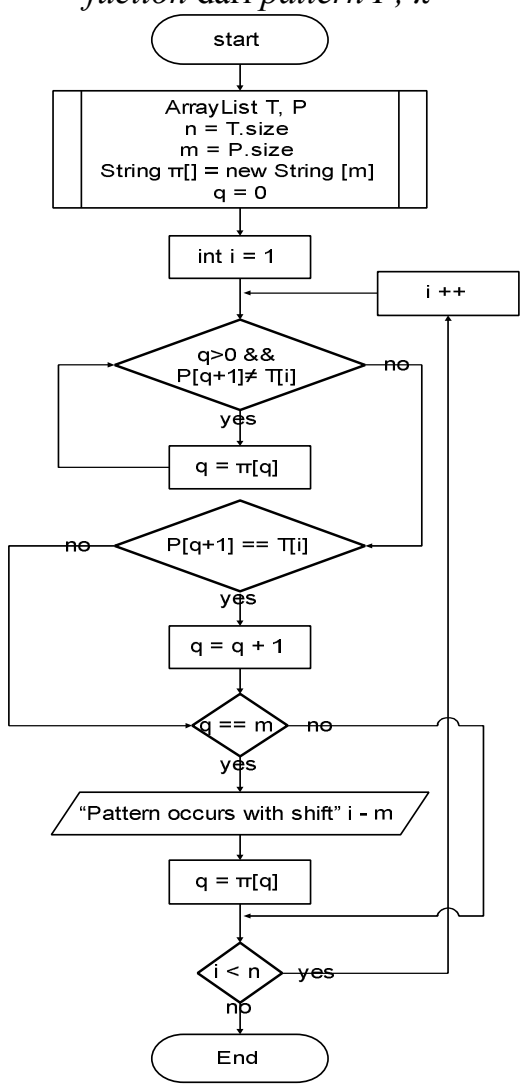

Gambar 4.FlowchartFase pencarian 


\section{F. Desain Interface}

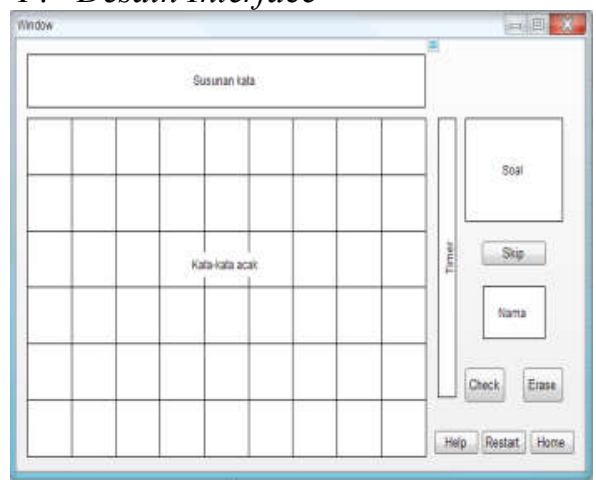

Gambar 5. Desain framepermainan

G. Desain Use Case Diagram

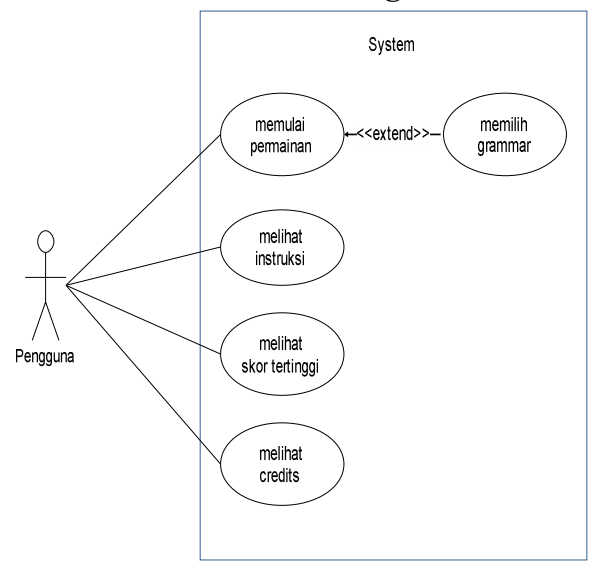

Gambar 6. Use Case Diagram untuk interaksi antara aktor dan sistem

\section{H. Desain Class Diagram}

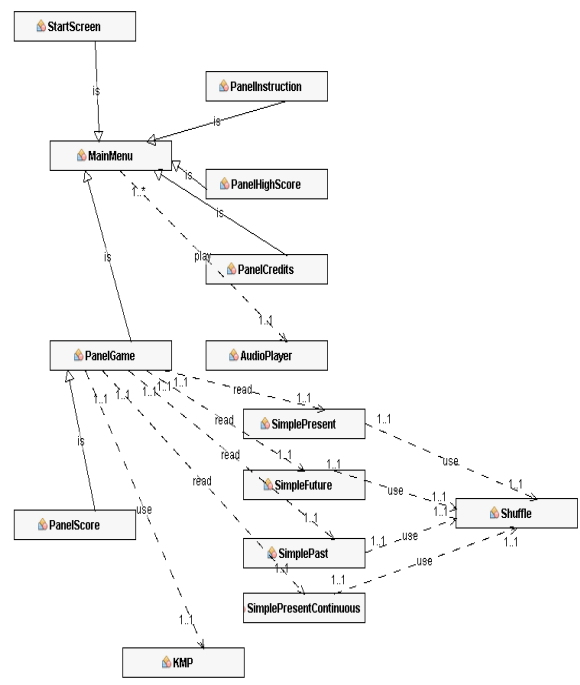

Gambar 7. Class Diagramaplikasi
I. Desain Activity Diagram

Pengguna

Aplikasi Komputer Interaktif

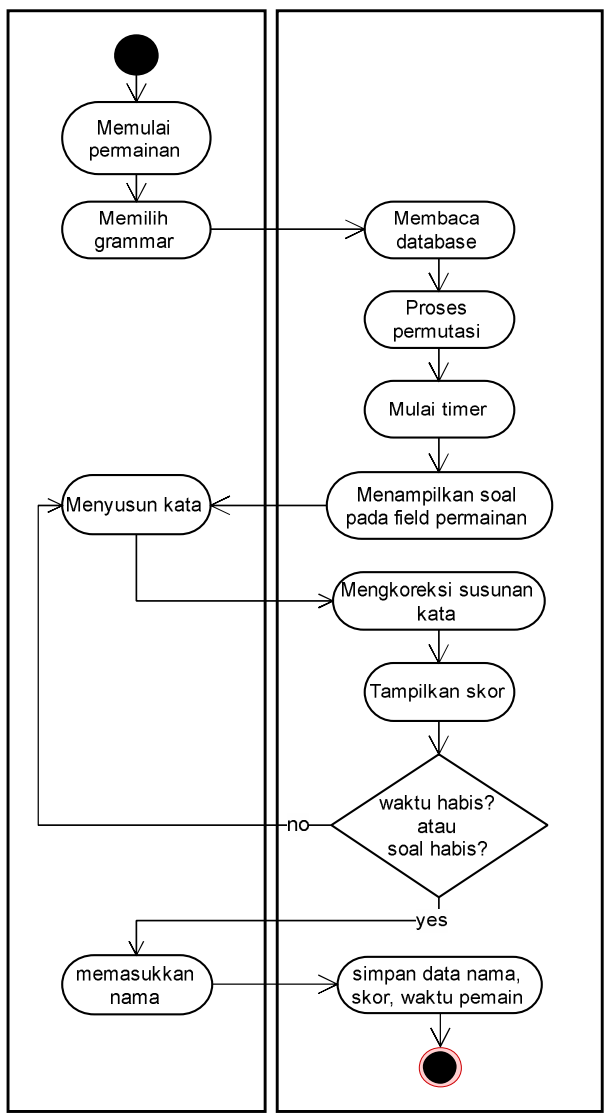

Gambar 8.Activity diagram aplikasi

IV. HASIL DAN PEMBAHASAN

A. Implementasi Interface permainan

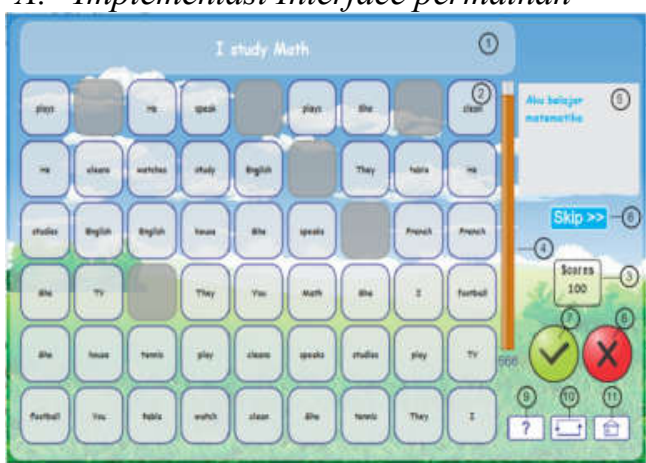

Gambar 9. Frame Permainan

B. Uji Coba Metode Fisher-Yates shuffle

Frequency analysis, dilakukan untuk mengetahui bahwa metode Fisher-Yates shuffle menghasilkan sebuah permutasi acak dari suatu himpunan terhingga (array) yang 
memiliki kemungkinan yang sama (unbiased).Menggunakan arraya [] = $\{0,1,2\}$ sebagai array uji coba, kemudian dilakukan perulangan permutasi sebanyak 600, 6.000 dan 60.000 kali.Hasil uji coba permutasi metodeFisher-Yates shuffle akan dibandingkan dengan hasil permutasi yang didapatkan dengan menggunakan fungsi yang terdapat pada java untuk melakukan permutasi acakyaitu Collections.shuffle (Array).

Pada percobaan metodeFisherYates shuffle(Gambar 10) dengan jumlah perulangan 600 kali didapat frekuensi permutasi dengan range sebesar 20 (nilai frekuensi $\max$ - nilai frekuensi $\mathrm{min}$ ) atau $3.33 \%$ ( $\left.\frac{\text { nilairange }}{\text { jumlah perulangar }}\right), 6.000$ perulangan sebesar $74(1.23 \%)$ dan 60.000 perulangan $166(0.28 \%)$ dengan nilai rata-rata range sebesar $1,61 \%$. Sedangkan pada percobaan permutasi Collections.shuffle()

(Gambar 11) dengan jumlah perulangan 600 kali didapat frekuensi permutasi dengan range sebesar 36 (6.00\%), 6.000 perulangan sebesar 84 $(1.40 \%)$ dan 60.000 perulangan 264 $(0.44 \%)$ dengan nilai rata-rata range sebesar 2,61\%. Frekuensi permutasi yang dihasilkan metode Fisher-Yates shuffle memiliki nilai rata-rata range lebih kecil $(1,00 \%)$ jika dibandingkan dengan nilai rata-rata range fungsi Collections.shuffle() yang terdapat pada java.

\section{Uji coba Knuth-Morris-Pratt}

Pencarian, proses ini dilakukan sebagai simulasi koreksi susunan kalimat dengan membandingkan antara jawaban pemain terhadap kunci jawaban yang tersimpan dalam database. Database soal permainan berupa file teks akan dibaca dan ditampung pada struktur data ArraList sebagai teks T. Uji coba dilakukan terhadap database untuk soal Simple Present, Simple Present Continuous, Simple Past, Simple Future (will) dan dilakukan sebanyak 50 kali untuk masing-masing tipe soal dengan kondisi pattern(kalimat) P ditentukan secara acak. Uji coba digunakan untuk mengukur akurasi dan konsumsi waktu metode.

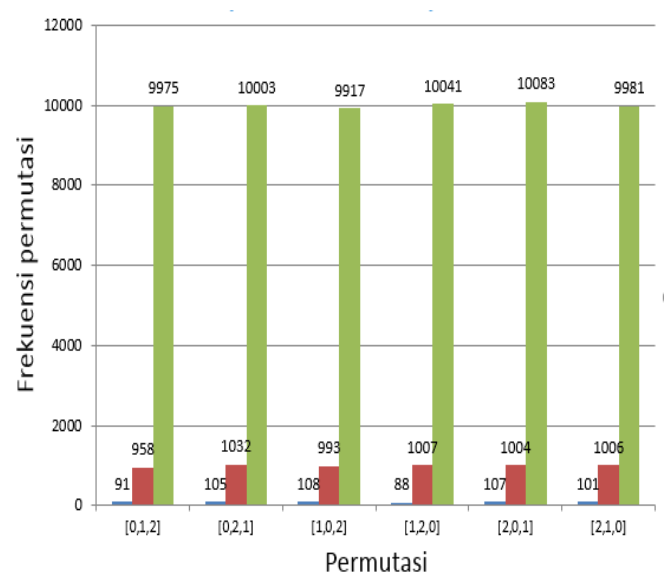

Gambar 10. Grafik frekuensi permutasi metode Fisher-Yates shuffle

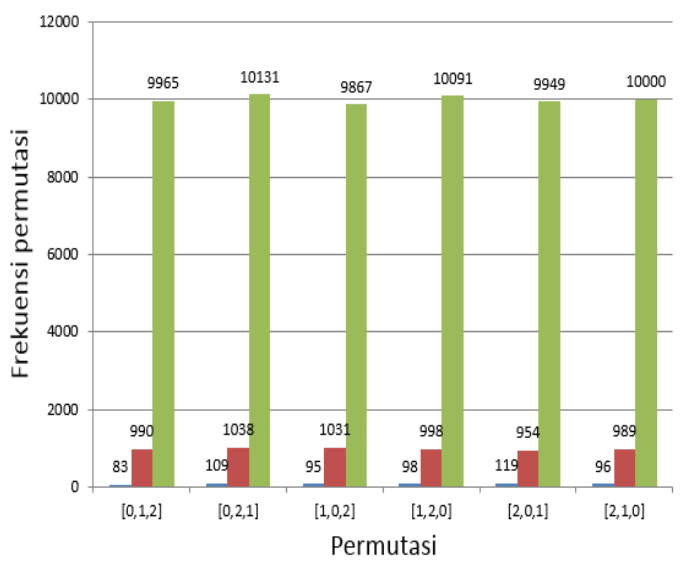

Gambar 11. Grafikfrekuensi permutasi Collections.shuffle()

Hasil uji coba akan didapatkan tabel dengan data berupa:

\begin{tabular}{|c|c|c|c|c|}
\hline & $\begin{array}{c}\text { Panjang } \\
\text { Pattern } \\
\text { (P) }\end{array}$ & $\begin{array}{c}\text { Panjang } \\
\text { Teks } \\
\text { (T) }\end{array}$ & & $\begin{array}{c}\text { Waktu } \\
\text { Eksekus } \\
\text { i (s) }\end{array}$ \\
\hline
\end{tabular}

Dari hasil 200 kali percobaan pencarian didapatkan grafik konsumsi waktu pencarian dapat dilihat pada gambar 12 . 


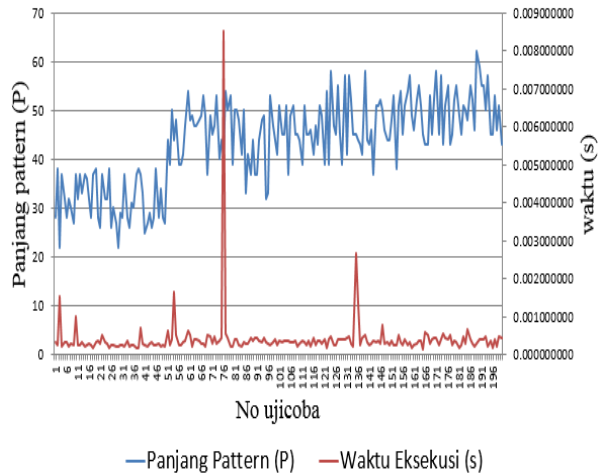

Gambar 12. Grafikkonsumsi waktu pencarian metode Knuth-Morris-Pratt

Panjang pattern $\mathrm{P}$ didapatkan dengan menghitung jumlah karakter pada pattern yang terpilih secara acak dengan teks T yang tidak berubah. Akurasi pada tabel uji coba diperoleh dengan melihat nilai kembalian methodKMP_matcher $(T, P)$

sebagaiio(kolom Jumlah Pergeseran (i0)).Apabila nilai kembalian bernilai 1 , artinya pattern $\mathrm{P}$ tidak ditemukan pada teks T. Apabila pattern $\mathrm{P}$ ditemukan pada teks $T$ maka nilai kembalian io bernilai bilangan cacah $(0,1,2, \ldots)$. Nilai io menunjukkan total banyaknya pergeseran terhadap teks $\mathrm{T}$ ketika pattern $\mathrm{P}$ ditemukan. Waktu eksekusi diperoleh dengan menghitung nilai selisih antara endTime - startTimepada kode uji coba. Rata-rata waktu eksekusi pada tabel hasil uji coba diperoleh dengan rumus sebagai berikut:

Rata-rata waktu eksekusi $=\frac{\text { Total wahtu }}{\text { Junlah percobasn }}$

Berdasarkan hasil uji coba yang telah dilakukan didapatkan hasil akurasi sebesar 100\%. Akurasi sebesar 100\% dapat diperoleh karena metode KnuthMorris-Pratt melakukan pencocokan string secara tepat (Exact String Matching). Metode string matching ini mencari string pada teks yang sama persis dengan string masukan. Kemudian didapatkan konsumsi waktu pencarian yang dibutuhkan aplikasi ratarata adalah 0,0004133403 $\left(4,133403 \times 10^{4}\right)$ detik.

\section{PENUTUP}

\section{A. Kesimpulan}

Berdasarkan hasil penelitian Aplikasi Permainan Susun Kata Untuk Pembelajaran Bahasa Inggris dengan Algoritma Knuth-Morris-Pratt dan Fisher-Yates Shuffle didapatkan kesimpulan sebagai berikut:

1. Hasil uji coba metode KnuthMorris-Pratt menunjukkan bahwa implementasi metode Knuth-MorrisPratt sebagai proses koreksi susunan kata pada aplikasi komputer interaktif bersifat efektif. Berdasarkan hasil uji coba yang telah dilakukan didapatkan hasil akurasi sebesar $100 \%$. Kemudian didapatkan konsumsi waktu pencarian yang dibutuhkan aplikasi rata-rata adalah $0,0004133403 \quad\left(4,133403 \times 10^{-4}\right)$ detik. Nilai akurasi dan konsumsi waktu yang didapatkan menunjukkan bahwa implementasi metode ini dapat berjalan maksimal dari segi akurasi dan kecepatan (konsumsi waktu $<0,5$ detik).

2. Hasil uji coba metode Fisher-Yates shufflemenunjukkan bahwa implementasi metode Fisher-Yates shuffle pada proses membangkitkan susunan soalpada aplikasi komputer interaktif bersifat efektif. Frekuensi permutasi yang dihasilkan metode Fisher-Yates shuffle memiliki nilai rata-rata range sebesar $1,61 \%$. Nilai tersebut lebih kecil $(1,00 \%)$ jika dibandingkan dengan nilai rata-rata range fungsi Collections.shuffle() yang terdapat pada java yaitu sebesar $2,61 \%$. Nilai tersebut membuktikan implementasi metode ini menghasilkan permutasi acak dari suatu himpunan terhingga dengan distribusi secara hampir merata pada sejumlah perulangan permutasi yang dilakukan. Hal tersebut menunjukkan bahwa susunan soal yang ditampilkan oleh aplikasi seimbang. Tidak ada susunan soal yang lebih mendominasi kemunculannya dari susunan soal 
lain sehingga soal yang ditampilkan permainan lebih bervariasi.

B. Saran

Pada Penelitian Aplikasi Permainan Susun Kata Untuk Pembelajaran Bahasa Inggris dengan Algoritma KnuthMorris-Pratt dan Fisher-Yates Shuffle menggunakan materi edukasi tata bahasa Inggris dalam bentuk kalimat positif dari Simple Present, Simple Present Continuous, Simple Past, dan Simple Future (will). Sehingga masih memungkinkan untuk dilakukan pengembangan lebih lanjut dengan materi edukasi 16 tensesyang lebih lengkap, atau menambah materi lain seperti Vocabulary, Spelling, dan lainlain.

\section{DAFTAR PUSTAKA}

[1]Andriasnyah, 2014. Perancangan Aplikasi Game Edukasi Menggunakan Metode Linear Congruent Method (LCM). Medan: Pelita Informatika Budi Darma, Volume : VI, Nomor: 1 ISSN : 2301-9425.

[2]Azhari \& Fatta, H.A., 2014. Pembuatan Game Design Document 'Vocab Mania' (Menyusun Gambar Dengan Kosa Kata Bahasa Inggris) Berbasis Android. Yogyakarta: Sekolah Tinggi Manajemen Informatika dan Komputer AMIKOM.

[3]Black, P.E., 2005. Fisher-Yates shuffle. [Online] Available at: HYPERLINK "http://xlinux.nist.gov/dads/HTML/fi sherYatesShuffle.html" http://xlinux.nist.gov/dads/HTML/fis herYatesShuffle.html [Accessed 5 April 2015].

[4]Cormen, T.H., Leiserson, C.E., Rivest, R.L. \& Stein, C., 2009. Introduction to Algorithms. 3rd ed. Massachusetts: The MIT Press.

[5]Frihardianto, Y., 2012. Penerapan Algoritma Generate And Test Pada
Permainan Scrabble. Yogyakarta: Undergraduate thesis, Duta Wacana Christian University. Retrieved from http://sinta.ukdw.ac.id.

[6]Hadiati, D., 2007. Penerapan Algoritma String Matching pada Permainan "Word Search Puzzle". Bandung: Makalah IF2251 Strategi Algoritmik.

[7] KEMENDIKNAS, 2011. Standar Kompetensi Lulusan. Direktorat Pembinaan Kursus \& Pelatihan.

[8]Lestari, S. \& Djaya, A., 2011. Aplikasi Search Engine Menggunakan Algoritma KnuthMorris-Pratt (KMP). Surabaya: Prosiding Seminar Nasional Manajemen Teknologi XIII.

[9]Masya, F. \& Elvina, 2010. Pengembangan Aplikasi Permainan Scrabble Dua Bahasa Menggunakan Java. Jakarta: Teknik Informatika, Universitas Mercu Buana.

[10] Muhammad, D.A.b., 2003. Tafsir Ibnu Katsir Jilid 5. Bogor: Pustaka Imam asy-Syafi'i.

[11] Mulyana, F., 2014. Penerapan Algoritma Knuth-Morris-Pratt Pada Game Puzzle Untuk Mencari Kecocokan Pola Warna. Bandung: Teknik Informatika, Fakultas Teknik dan Ilmu Komputer, Universitas Komputer Indonesia.

[12] Pandiselvam.P, Marimuthu.T \& Lawrance.R, 2014. A Comparative Study on String Matching Algorithm of Biological Sequences. Sivakasi: Department of Computer Applications, Ayya Nadar Janaki Ammal College, India.

[13] Rahmawati, S.R., 2007. Panduan Lengkap Menguasai English Grammar. Jakarta: PT Kawan Pustaka.

[14] Soleh, 2010. Implementasi Algoritma KMP dan Boyer-Moore dalam Aplikasi Search 
Engine Sederhana. Bandung: Makalah IF3051 Strategi Algoritma.
[15] Wardhaugh, R., 2010. An Introduction to Sociolinguistics. 6th ed. Oxford: Blackwell. 